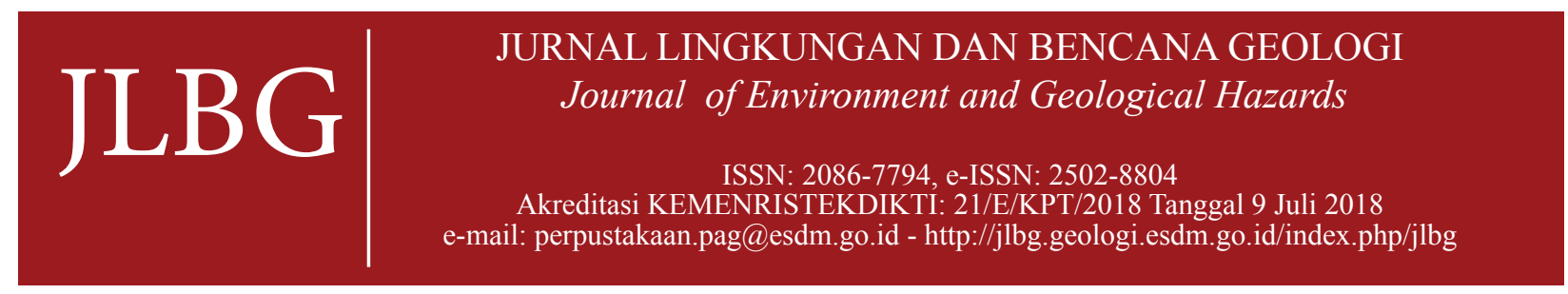

\title{
Peranan Geomorfologi dalam Perencanaan Bangunan pada Zona Ancaman Longsor Tinggi di Kawasan Geopark Karangsambung-Karangbolong Bagian Utara
}

\section{The Role of Geomorphology in Building Planning in the High Landslide Hazard Zone in the Geopark Karangsambung-Karangbolong}

\author{
Puguh Dwi Raharjo, Kristiawan Widiyanto, Sueno Winduhutomo, dan Moh. Al'Afif
}

Balai Informasi dan Konservasi Kebumian, Lembaga Ilmu Pengetahuan Indonesia Jalan Karangsambung KM 19 Kebumen Jawa Tengah, Indonesia

Naskah diterima 11 Mei 2019, selesai direvisi 05 November 2019, dan disetujui 25 November 2019

e-mail: puguh.draharjo@karangsambung.lipi.go.id

\begin{abstract}
ABSTRAK
Kawasan Karangsambung Kabupaten Kebumen, Jawa Tengah merupakan Cagar Alam Geologi yang sekaligus merupakan Kawasan Geopark Karangsambung-Karangbolong. Fungsi edukasi, konservasi, wisata serta pemberdayaan masyarakat menjadi fokus pembangunan dari pemerintah daerah pada kawasan geopark. Pemerataan pembangunan terutama sektor-sektor penting di kawasan geopark sangat diperlukan. Ancaman longsor pada bagian utara kawasan Geopark Karangsambung Karangbolong memiliki kriteria ancaman tinggi hingga sedang dan hanya sedikit yang memiliki kriteria rendah. Hal ini menjadikan hambatan pembangunan terutama untuk pelayanan apabila tidak dipetakan secara detail lokasi-lokasi strategis pada lahan kepemilikan pemerintah daerah. Penelitian mengenai gerakan tanah sudah banyak dilakukan namun masih dalam skala yang kecil berupa spasial, namun masih jarang yang melakukan penelitian dalam skala besar. Penelitian ini bertujuan untuk melakukan analisis kelayakan lokasi yang memiliki status kepemilikan oleh pemerintah daerah Kabupaten Kebumen pada wilayah yang rawan terhadap ancaman longsor. Status ancaman longsor lokasi tersebut dapat digunakan sebagai bahan pertimbangan Pemerintah Kabupaten Kebumen dalam perencananaan bangunan strategis. Metode yang digunakan dalam penelitian ini adalah pendekatan analisis spasial (intepretasi bentulahan dan perkembangan lereng), pengukuran lapangan (mengetahui rembesan air dan bentukan bekas nendatan, sampel tanah, dan pembuatan data DEM), dan data laboratorium (uji sifaf fisik tanah). Hasil yang diperoleh bahwa bangunan fisik berupa kantor masih dapat direncanakan pada lokasi tertentu di zona ancaman longsor tinggi. Site selection ini dapat digunakan sebagai acuan untuk pembangunan wilayah dalam rangka mendukung pengembangan Geopark Nasional Karangsambung-Karangbolong.
\end{abstract}

Kata kunci: Geopark Karangsambung-Karangbolong, Kebumen, longsor, pemilihan lokasi, perencanaan.

\section{ABSTRACT}

Karangsambung is a Geological Nature Reserve that is part of the National Geopark. The function of education, conservation, tourism and community empowerment makes the development focus of the local government on geopark. Equitable development, especially important sectors in the geopark area, is needed. The threat of landslides in the northern part of the Karangsambung Karangbolong Geopark area has high to moderate threat criteria and only a few have low criteria. Research on landslides that have been carried out has a small scale. This makes development 
barriers especially for services if not mapped in detail strategic locations on local government land ownership. Research on soil movement has been done a lot but still on a small scale in the form of spatial, but still rarely do research on a large scale. This study aims to conduct a site feasibility analysis that has ownership status by the Kebumen Regional Government in an area prone to landslide threats. Status of landslide threat the location can be used as a consideration for the Kebumen Regency in planning strategic buildings. The methods used in this study is an approach with field data, laboratory data and a spatial analysis approach. The results obtained that physical buildings in the form of offices can still be planned at certain locations in the threat zone of high landslides. This site selection can be used as a reference for regional development in order to support the development of the KarangsambungKarangbolong National Geopark..

Keywords: Karangsambung-Karangbolong Geopark, Kebumen, Landslides, Planing, Site selection.

\section{PENDAHULUAN}

Geomorfologi bentuk lahan dapat digunakan sebagai unit karakteristik dengan memiliki kesamaan yang dipengaruhi oleh faktor topografi dan struktur geologi serta proses eksogen (Raharjo drr, 2014). Kajian mengenai bentuk lahan sekaligus dapat mewakili kondisi lereng, drainase, serta tanah secara umum (Raharjo, 2008). Gerakan tanah merupakan salah satu proses geomorfologi yang terjadi pada suatu lereng perbukitan dan/atau pegunungan (Priyono, 2011). Longsor merupakan proses material permukaan bergerak oleh adanya gaya gravitasi baik lambat atau cepat dari suatu tempat ke tempat lain (Zuidam, 1983). Prosesproses geomorfologi yang telah terjadi pada masa lampau tidak hanya berdasarkan pada morfologi bentuk lahan saja, namun juga pada material penyusun bentuklahan yang salah satunya adalah tanah (Sartohadi, 2008).

Lereng dalam waktu panjang akan berevolusi dan material permukaan pada lereng akan bergerak turun karena gaya gravitasi (Pramudjiono dan Karnawati, 2008). Kondisi kemiringan lereng menjadi faktor pengontrol untuk terjadinya gerakan tanah (Karnawati. 2002). Lereng yang stabil merupakan lereng yang memiliki keseimbangan dan tidak mudah untuk longsor, ketika terdapat gangguan maka akan terjadi ketidakseimbangan dan mengakibatkan ketidakteraturan kondisi lereng (Zakaria, 2010).

Selain kemiringan lereng faktor litologi, struktur geologi, kondisi air tanah, tata guna lahan, serta intensitas curah hujan juga mempengaruhi ancaman gerakan tanah (Soebowo drr, 2002; Iskandar drr, 2006). Faktor internal merupakan gangguan yang datang dari dalam tubuh lereng sendiri, terutama karena adanya peran air dalam tubuh lereng yang tak lepas dari pengaruh luar (curah hujan). Kenaikan kadar air tanah akan menurunkan sifat fisik dan mekanik tanah serta meningkatkan tekanan pori, akibatnya lebih banyak fraksi halus (lanau) massa tanah yang dihanyutkan, lebih jauh ketahanan massa tanah akan menurun.

Vegetasi merupakan salah satu teknologi alternatif dalam mengurangi longsor dangkal (Mulyono drr., 2017). Faktor kestabilan lereng dapat ditingkatkan dengan adanya vegetasi pada lereng, sehingga perakaran akan memperkuat tanah dan evapotranspirasi untuk mengurangi kejenuhan tanah (Switala dan Wu, 2019; Viet drr, 2016). Pada beberapa tempat kejadian longsor memiliki polapola vegetasi tertentu (Carone drr., 2017), studi pengaruh tutupan vegetasi terhadap kestabilan lereng juga tidak selalu konsisten tergantung dari kondisi daerahnya (Viet drr., 2016).

Kawasan Karangsambung merupakan Cagar Alam Geologi yang menjadi bagian dari Geopark Nasional. Fungsi edukasi, konservasi, wisata serta pemberdayaan masyarakat menjadi fokus pembangunan dari pemerintah daerah pada kawasan geopark. Pembangunan terutama pada sektor-sektor penting (infrastruktur, fasilitas umum, dan kantor pelayanan masyarakat) di kawasan geopark perlu dilakukan pemerataan. Hal ini menunjang untuk keberlangsungan geopark di masa yang akan datang.

Perbukitan merupakan dominasi morfologi yang berada pada bagian utara pada kawasan ini (Raharjo drr., 2011), kebencanaan terutama gerakan tanah perlu dijadikan perhatian dalam pembangunan di Kawasan Geopark Karangsambung-Karangbolong. Penelitian sebelumnya oleh Raharjo dan Nur (2013) melakukan pemetaan ancaman longsor pada kawasan tersebut. Hasil yang diperoleh bahwa ancaman longsor pada bagian utara (Kecamatan Karangsambung dan Kecamatan Sadang) memiliki kriteria ancaman tinggi hingga sedang dan hanya sedikit yang memiliki kriteria rendah. Tingginya 
Peranan Geomorfologi dalam Perencanaan Bangunan pada Zona Ancaman Longsor Tinggi di Kawasan

Geopark Karangsambung-Karangbolong Bagian Utara

ancaman longsor pada Kawasan Geopark Karangsambung Karangbolong bagian utara, bukan menjadi penghambat untuk perencanaan pembangunan infrastruktur pemerintah. Lokasilokasi pada kawasan utara ini perlu didorong untuk kemajuan dan pengembangan geopark.

Penelitian mengenai pemetaan gerakan tanah sudah banyak dilakukan namun masih dalam skala yang menengah dan bersifat umum, masih jarang yang melakukan penelitian untuk pemetaan dalam skala besar dengan informasi yang detail. Penelitian ini perlu dilakukan guna mengetahui secara jelas dan detail lokasi-lokasi yang memiliki kategori aman pada daerah dengan kategori ancaman longsor tinggi pada skala menengah. Penelitian ini merupakan analisis detail yang sangat mempertimbangkan faktor geomorfologi. Penelitian ini bertujuan untuk melakukan analisis kelayakan lokasi yang memiliki status kepemilikan oleh Pemerintah Daerah Kebumen pada wilayah yang rawan terhadap ancaman longsor yang akan digunakan untuk bangunan kantor milik pemerintahan. Sehingga dengan diketahuinya status ancaman longsor lokasi tersebut dapat digunakan sebagai bahan pertimbangan Pemerintah Kabupaten Kebumen dalam perencananaan bangunan pemerintahan yang strategis. Bangunan pemerintahan pada lokasi kawasan Geopark Karangsambung Karangbolong sebelah utara ini akan bermanfaat dan berperan untuk memberikan pelayanan kepada masyarakat yang secara umum dalam pengembangan kawasan geopark.

\section{METODE PENELITIAN}

Kegiatan ini dilakukan di Desa Sadang Kulon Kecamatan Sadang Kabupaten Kebumen. Lokasi berada di pinggir jalan dengan Koordinat UTM 358872mT; 9169098mU (Gambar 1). Pada penelitian ini digunakan beberapa alat antara lain, yaitu: drone, bor tanah, tabung sampel tanah, kompas geologi, GPS serta data sekunder berupa peta geologi dan peta topografi.

Pada penelitian ini menggunakan analisis keruangan serta analisis data lapangan serta laboratorium. Pada analisis data lapangan beberapa kegiatan yang dilakukan antara lain, adalah: pengambilan sampel tanah (laboratorium); pengukuran lereng setiap segmen yang ditentukan; pengukuran ketebalan tanah secara umum; survei kontak litologi dan struktur geologi; mencari bekas longsoran yang telah terjadi dan tanda-tanda kemungkinan terjadinya longsoran; mencari rembesan-rembesan air pada tanah; dan perhitungan fs (factor of safety) di setiap segmen lereng (Vernes, 1978).

Pada analisis keruangan pada penelitian ini dilakukan beberapa kegiatan yang dilakukan antara lain, adalah: Intepretasi bentuklahan; pemetaan skala detail dengan menggunakan drone; dan pembuatan serta analisis DEM (digital elevation model). Data DEM diturunkan dari hasil pemotretan melalui drone yang dibuat orthomosaic. Sistem koordinat dalam pemetaan menggunakan proyeksi UTM datum WGS 1984. Ground control point (GCP) menggunakan kenampakan yang mudah dikenali di lapangan (persimpangan jalan dan alur



Gambar 1. Lokasi daerah penelitian Kecamatan Sadang Kabupaten Kebumen 


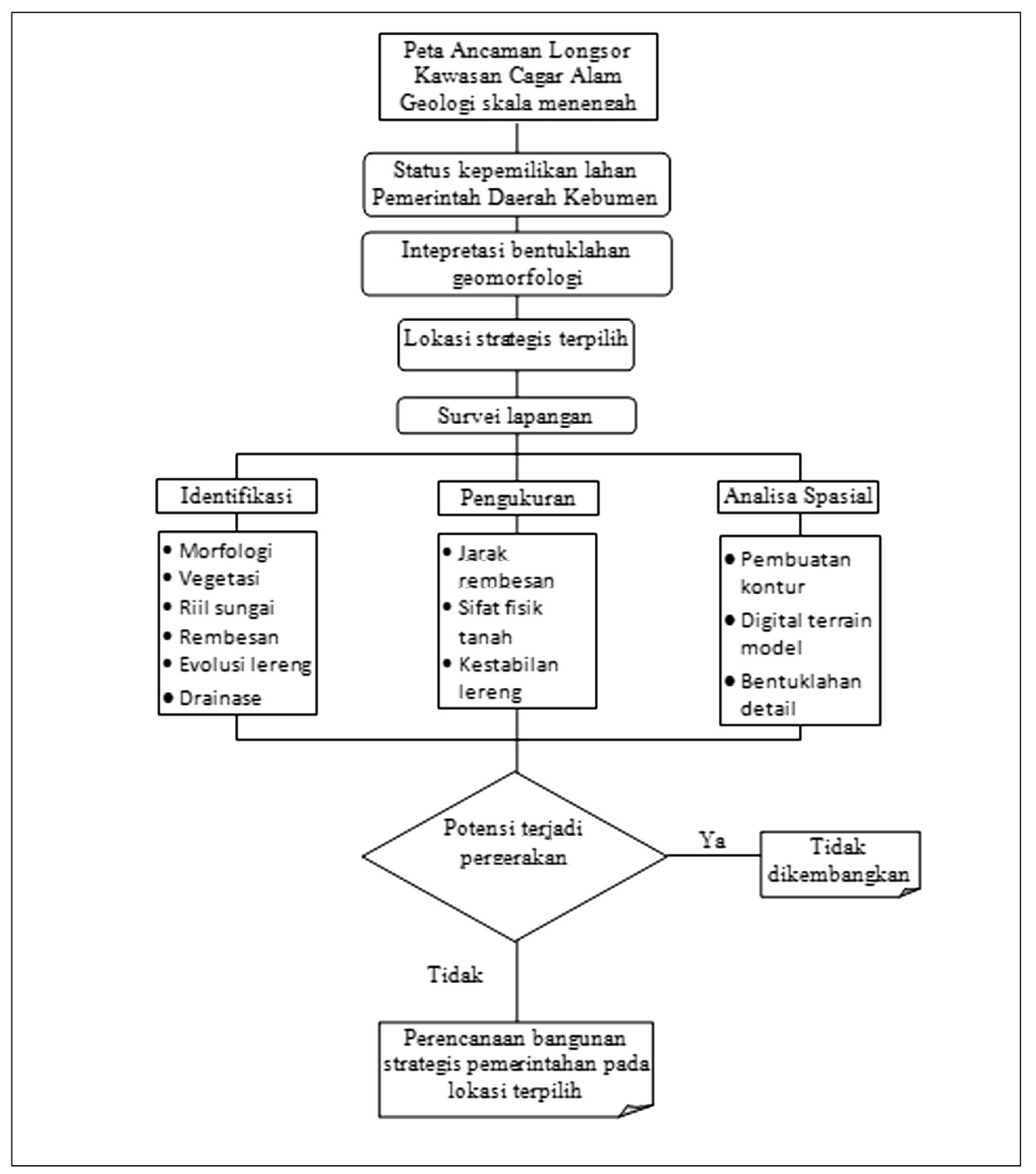

Gambar 2. Diagram alir penelitian

sungai), sedangkan untuk ground altitude diukur menggunakan GPS (global positioning system).

\section{HASIL DAN PEMBAHASAN}

Daerah penelitian merupakan zona mélange yang banyak tersingkap batuan-batuan berumur tua. menurut Asikin (1974) merupakan daerah dimana batuan pra-Tersier tersingkap dengan susunan dan struktur geologi yang rumit, kelompok batuan pra-Tersier sebagian besar terdiri dari satuan-satuan batuan yang sifatnya terpotongpotong, terbreksikan dan memperlihatkan gejala penggerusan. Secara umum, jenis penutup lahan Vegetasi bermozaik bercampur dengan lahan terbuka merupakan jenis penggunaan lahan yang didalamnya juga terdapat pemukiman desa dan juga pekarangan dengan berbagai vegetasi.
Lokasi penelitian merupakan lahan milik Pemerintah Daerah Kebumen yang akan digunakan sebagai kantor pemerintahan. Fokus penilaian lokasi pada penelitian ini adalah pada kajian wilayah insitu dari risiko longsor. Selain itu juga mempertimbangkan aspek lain yang mempengaruhi penilaian untuk pemilihan lokasi tersebut untuk bangunan perencanaan kantor pemerintahan.

Pada tahapan awal analisis data keruangan sangat diperlukan, hal ini guna mengetahui kondisi permukaan secara menyeluruh. Pertimbangan aksesibilitas jalan merupakan faktor penting dalam pemilihan lokasi perencanaan bangunan pada tanah milik Pemerintah Kabupaten Kebumen. Akses jalan pada lokasi penelitian berada pada jalan kecamatan yang pada perencanaan 
Peranan Geomorfologi dalam Perencanaan Bangunan pada Zona Ancaman Longsor Tinggi di Kawasan

Geopark Karangsambung-Karangbolong Bagian Utara

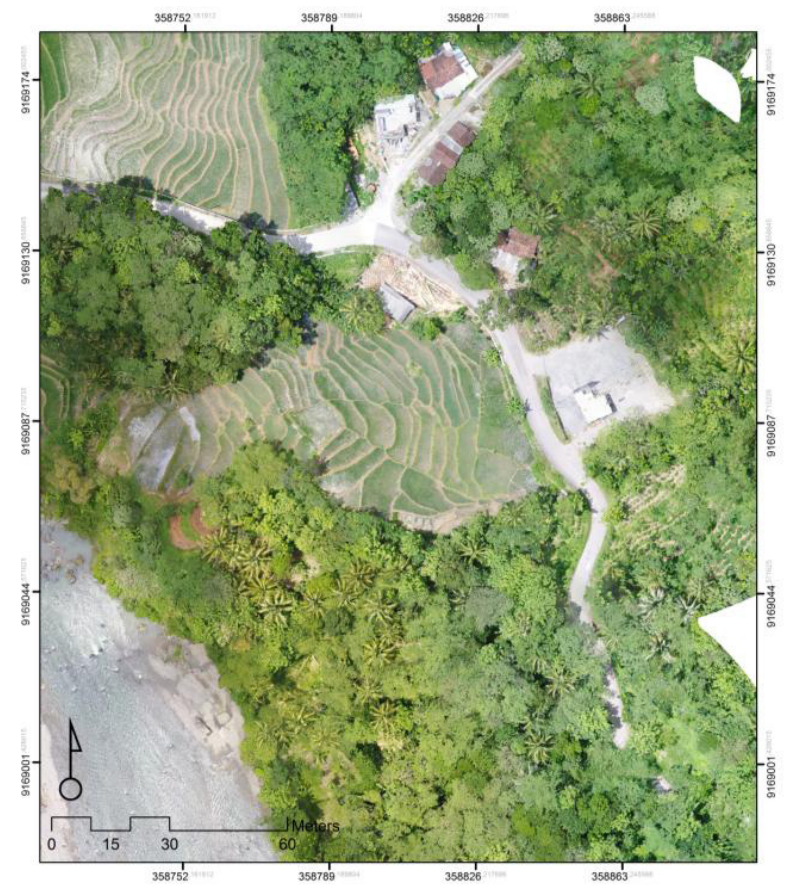

Gambar 3. Kenampakan vegetasi pada sekitar lokasi penelitian (Sumber: Pemetaan drone, 2019)

Kabupaten Kebumen akan berubah menjadi jalan kabupaten yang menghubungkan dengan Kabupaten Banjarnegara. Aksesibilitas dapat merangsang pertumbuhan pusat-pusat ekonomi, aktivitas masyrakat juga semakin mudah dan berkembang (Farida, 2013). Pada lokasi kegiatan merupakan daerah dengan karakterstik wilayah dengan penduduk yang berkelompok yang jauh dengan kelompok penduduk yang lain. Pola dan distribusi penduduk pada lokasi tersebut juga dapat digunakan sebagai dasar perencanaan bangunan pemerintah. Konektivitas penduduk menjadi bagian yang penting dalam perencanaan wilayah, sehingga wilayah akan berkembang dengan baik (Shara, 2018).

Analisis data keruangan juga untuk mengetahui jenis bentuklahan yang akan digunakan untuk mengintepretasi kenampakan longsor. Lokasi kegiatan merupakan suatu daerah dengan tutupan vegetasi yang berbeda dengan lokasi sekitarnya (Gambar 3). Pada lereng bagian tengah hingga atas berupa tanaman vegetasi kerapatan rendah, sedangkan lereng pada bagian bawah berupa sawah yang memiliki kelembaban tinggi. Kelembaban tanah merupakan faktor penting dalam kejadian longsor, kegagalan lereng merupakan fungsi dari kemiringan lereng dan kelembaban tanah (Pelletier drr., 1997).
Jenis tanaman memiliki perbedaan antara daerah yang berupa cekungan dengan lereng perbukitan yang berada di sekitarnya. Vegetasi yang dominan berada pada cekungan (lereng tengah hingga atas) tersebut berupa tanaman campuran berkerapatan rendah dengan dominasi antara lain berupa tanaman singkong, pisang, kelapa dan bambu. Sedangkan pada perbukitan yang berada di sekitar daerah ini, jenis vegetasinya berupa tanaman keras dengan kerapatan sedang hingga tinggi. Pada lereng bagian bawah di dominasi oleh lahan pertanian sawah, kondisi ini juga terdapat perbedaan dengan jenis tutupan lahan vegetasi yang ada di sekitarnya. Pada daerah di sekitar lokasi kegiatan jenis penggunaan yang dominan berupa kebun campuran. Cara umum untuk mendeteksi lokasi longsor adalah perubahan pola vegetasi yang ada (Plank drr., 2016), Pada lokasi penelitian juga menunjukkan perbedaan pola vegasi dari vegetasi kerapatan tinggi pola vegetasi kerapatan rendah.

Tanaman-tanaman inimemberikaninformasibahwa kondisi lahan memiliki karakteristik yang berbeda, sehingga tanaman eksisting juga menyesuaikan dengan kondisi lingkungan berada. Jenis pertanian sawah menandakan bahwa kondisi air yang tersedia pada daerah tersebut cukup melimpah. Ketersediaan air ini berupa air permukaan yang dapat berasal dari parit sungai akibat rembesan pada permukaan. Rembesan air yang berada pada lereng mengikuti takik-takik lereng yang berbentuk nendatan tanah (slumping). Selain itu adanya pertemuan lapisan antara tanah (regolit) dan batuan dasar juga dapat mengakibatkan munculnya rembesan air dipermukaan. Kelembaban tanah merupakan sistem dinamika yang mempengaruji terjadinya longsor (Pelletier drr, 1997).

Selain ketersediaan air yang cukup, faktor tanah bertekstur lempung juga mempengaruhi jenis vegetasi pada lokasi tersebut. Sedangkan pada lereng atas memiliki kemiringan, ketebalan tanah dan tekstur tanah berbeda, sehingga keberadaan penutup lahan juga berbeda. Selama kurun waktu empat tahun 2015 (Google inc, 2015) hingga 2019 tidak ada perubahan jenis tutupan vegetasi dominan serta bentuk yang mencolok. Tanaman-tanaman keras tidak ada yang mengindikasikan adanya rayapan tanah pada lokasi kajian. Pada penelitian ini pemetaan dalam skala detail menggunakan pemotretan udara dengan wahana drone. Jalur terbang searah mengikuti hadap kemiringan lereng ke arah selatan dengan resolusi spasial sekitar \pm 50 


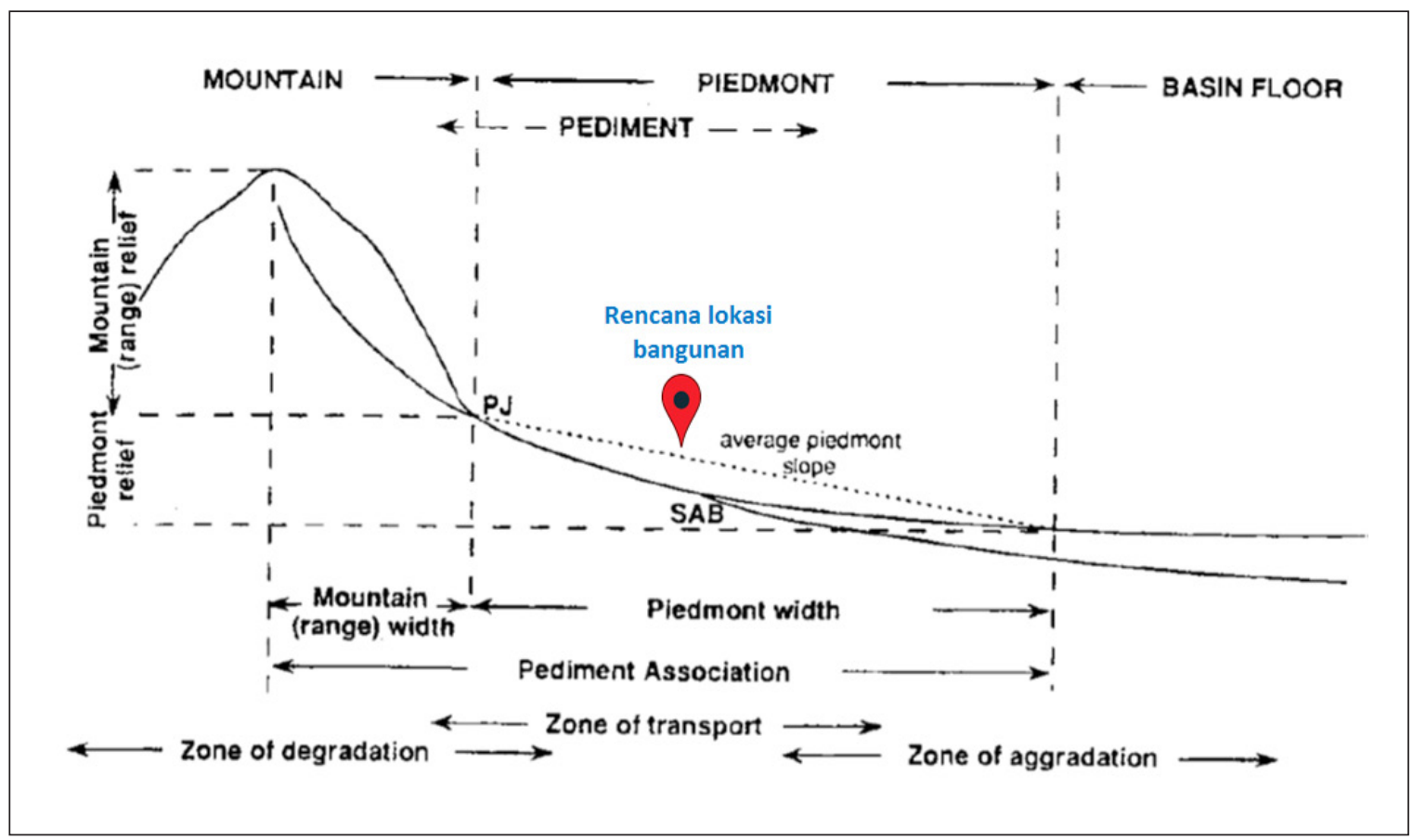

Gambar 4. Asosiasi pedimen, $\mathrm{PJ}=$ Batas pedimen dengan daerah atas; $\mathrm{SAB}=$ Bentukan pedimen (Cooke, 1970 dalam Bösken, 2013 dengan modifikasi).

mm. Intepretasi menggunakan metode visual untuk analisis bentukan lahan dipermukaan yang terjadi.

Lokasi kajian merupakan daerah yang berada di lereng bawah-tengah dengan topografi relatif landai. Daerah ini merupakan bentukanlahan berupa pedimen yang banyak dipengaruhi oleh endapan dari lereng atas. Pedimen ini berada di atas batuan induk (bedrock) berupa sekismika yang mengalami kontak dengan batuan berupa breksi (lereng tengah). Secara geologi lokasi kajian merupakan pertemuan antara Kompleks Melange dengan Formasi Totogan. Pedimen merupakan batas antara zona perbukitan dengan dataran aluvial. Secara keseluruhan dari wilayah ini merupakan wilayah perbukitan yang telah mengalami degradasi lahan menjadi cekungan.

Kemiringan lereng pada pada lokasi kegiatan dibagi menjadi 3 segmen, yaitu segmen A di bagian bawah, segmen B di bagian tengah, dan segmen $\mathrm{C}$ di bagian atas. Lokasi A (Gambar 5) merupakan daerah perbatasan antara perbukitan dengan sungai. Bentukan morfologi tebing sungai terkesan ada bentukan menonjol keluar (arah sungai). Tipe sungai yang berkembang hampir membentuk suatu bentukan meandering (berkelok-kelok). Namun kenampakan yang terlihat pada saat ini meandering tersebut sudah terganggu, terdapat adanya endapan

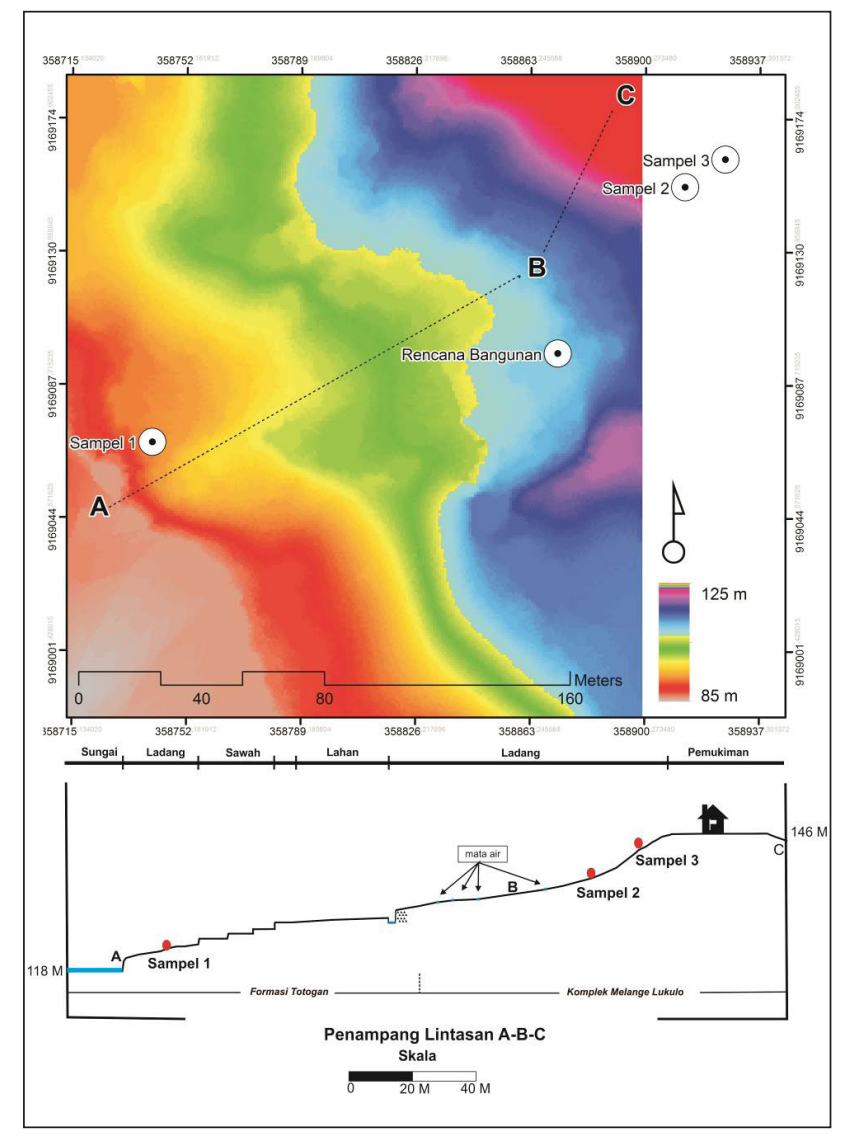

Gambar 5. Model spasial permukaan di lokasi kegiatan 
Peranan Geomorfologi dalam Perencanaan Bangunan pada Zona Ancaman Longsor Tinggi di Kawasan

Geopark Karangsambung-Karangbolong Bagian Utara

yang seolah-olah pernah terjadi gerakan tanah pada waktu terdahulu (Gambar 6.D). Hal ini berakibat sungai terdesak dan perkembangan meandering tidak terjadi secara ideal.

Ciri dari sungai meandering pada lekukan luar terdapat adanya pothole (lubang) dengan air yang dalam, namun yang terjadi pada lokasi ini dasar permukaannya adalah dangkal. Pointbar-pointbar selain terdapat pada lekukan sisi dalam, pada lokasi A juga ditemukan pada sisi lekukan luar. Kondisi pada tubuh air sungai juga banyak ditemukan bongkah-bongkah batuan yang berbeda-beda yang berkumpul pada satu tempat. Wilayah ini juga merupakan tempat keluaran mata air dari cekungan atas, sehingga terkesan seperti daerah tangkapan air untuk kajian lokal.

Pada lokasi B terdapat kemiringan lereng rendah hingga sedang (0-13\%). Pada lokasi ini banyak ditemukan rembesan-rembesan air dari dalam tanah melalui mikro takik lereng, tanah relatif terasa sangat lunak. Keluarnya rembesan air ini dimungkinkan karena adanya lapisan tanah yang tipis bertemu dengan batuan induk sekismika, antara zona permeabilitas dan zona impermeabilitas. Pada segmen ini terlihat nendatan tanah yang pernah terjadi dengan gerakan yang sangat lambat. Selain itu adanya kontak batuan antara breksi serta sekismika dimungkinkan untuk terjadinya sliding/ longsoran. Pada lereng sebelah barat, terlihat adanya longsoran berupa jatuhan (rock fall) pada batuan induk berupa breksi, namun longsoran ini tidak berdampak pada nendatan di segmen B.

Lokasi C memiliki tanah yang relatif tipis dan ditemukan beberapa titik batuan induk yang tersingkap. Kemiringan sangat curam namun tidak ditemukan rembesan-rembesan air. Pada segmen ini terdapat alur sungai dari sebelah timur yang menerus sampai ke bawah, namun pada sisi sebelah barat alur sungai baru terbentuk pada ketinggian tersebut dan menerus hingga ke bawah. Sehingga permukaan yang diapit oleh kedua riil, air akan mudah masuk ke dalam tanah dan kemungkinan terjadinya longsor semakin tinggi juga. Kondisi tanah relatif padat dan banyaknya ditemukan regolit dari pelapukan batuan sekismika.

Keairan merupakan faktor penting lainnya yang dapat memicu terjadinya gerakan tanah terutama curah hujan. Air permukaan yang berasal dari curah hujan, sebagian akan meresap ke dalam tanah/ batuan melalui pori-pori tanah atau retakan-retakan yang terdapat pada tanah atau batuan dan sebagian lagi akan mengalir di atas permukaan tanah. Hal ini akan meyebabkan perubahan terhadap sifat fisik tanah, yaitu menurunnya harga kohesi tanah, berkurangnya kuat geser tanah dan bertambahnya bobot massa tanah.

Pengujian laboratorium dari sampel tanah, diperoleh hasil nilai seperti yang terlihat pada table diatas. Jika kita lihat nilai kadar air sampel 1

Tabel 1. Hasil uji sifat fisik tanah daerah penelitian

\begin{tabular}{|c|c|c|c|c|c|}
\hline Keterangan & \multicolumn{2}{|c|}{ Karakteristik berat-volume } & \multirow{2}{*}{$\begin{array}{c}\text { Sampel } 1 \\
75,7\end{array}$} & \multirow{2}{*}{$\begin{array}{c}\text { Sampel } 2 \\
46,44\end{array}$} & \multirow{2}{*}{$\begin{array}{c}\text { Sampel } 3 \\
35,58\end{array}$} \\
\hline Kadar Air & $\mathrm{w}$ & $\%$ & & & \\
\hline Berat Jenis & Gs & & 2,62 & 2,71 & 2,66 \\
\hline Berat Isi Asli & $\Upsilon$ & $\mathrm{g} / \mathrm{cm} 3$ & 1,543 & 1,49 & 1,64 \\
\hline Berat Isi Kering & $\Upsilon \mathrm{d}$ & $\mathrm{g} / \mathrm{cm} 3$ & 0,878 & 1,021 & 1,211 \\
\hline Berat Isi Jenuh & Ysat & $\mathrm{g} / \mathrm{cm} 3$ & 1,543 & 1,645 & 1,755 \\
\hline Porositas & $\mathrm{n}$ & $\%$ & 66,49 & 62,37 & 54,41 \\
\hline Angka Pori & $\mathrm{e}$ & & 1,98 & 1,66 & 1,19 \\
\hline Derajat Kejenuhan & $\mathrm{Sr}$ & $\%$ & 99,96 & 76,01 & 79,21 \\
\hline Batas Cair & LL & $\%$ & 70,93 & 41,35 & 43,24 \\
\hline Batas Plastis & PL & $\%$ & 42,54 & 27,36 & 33,81 \\
\hline Indeks Plastis & IP & $\%$ & 28,39 & 13,99 & 9,43 \\
\hline \multirow[t]{2}{*}{ Lempung } & $<0,002 \mathrm{~mm}$ & $\%$ & 2,80 & & \\
\hline & $<0,005 \mathrm{~mm}$ & $\%$ & 31,00 & 18,85 & 15,87 \\
\hline Lanau & $0,005-0,075 \mathrm{~mm}$ & $\%$ & 41,14 & 39,93 & 33,79 \\
\hline Pasir Halus & $0,075-0,420 \mathrm{~mm}$ & $\%$ & 18,10 & 27,22 & 24,70 \\
\hline Pasir Sedang & $0,420-2,000 \mathrm{~mm}$ & $\%$ & 6,96 & 14,00 & 25,64 \\
\hline Pasir Kasar & $2,000-4,750 \mathrm{~mm}$ & $\%$ & 0,00 & 0,00 & 0,00 \\
\hline Kerikil & $>4,750 \mathrm{~mm}$ & $\%$ & 0,00 & 0,00 & 0,00 \\
\hline
\end{tabular}


Tabel 2. Hasil Uji Sifat Aktif dan Pengembangan

\begin{tabular}{llllll}
\hline $\begin{array}{l}\text { Lokas i } \\
\text { Sampel }\end{array}$ & $\begin{array}{l}\text { Indeks plas- } \\
\text { tis }(\%)\end{array}$ & $\begin{array}{l}\text { Fraksi } \\
\text { pung }(\%)\end{array}$ & $\begin{array}{l}\text { Lem- } \\
\text { Keaktifan }\end{array}$ & Keaktifan & Pengembangan \\
\hline 1 & 28,39 & 33,80 & 0,84 & Normal & Sedang \\
2 & 13,99 & 18,85 & 0,74 & Tidak Aktif & Rendah \\
3 & 9,43 & 15,87 & 0,59 & Tidak Aktif & Rendah \\
\hline
\end{tabular}

memiliki kadar air yang tinggi, sedangkan sampel 2 dan 3 sedang. Tanah jenuh akan air menyebabkan derajat kejenuhan dan tekanan air pori meningkat, hal tersebut berpengaruh terhadap terganggunya kestabilan lereng.

Nilai distribusi ukuran butir tingkat pelapukan tanah menengah, dilihat dari butiran yang lolos saringan $200(<0,0075 \mathrm{~mm})$ menunjukkan angka $\pm 30 \%$, ukuran lempung $\pm 15 \%$ lainnya merupakan lanau dan pasir halus. Selain itu didukung dengan hasil uji berat jenis, diperoleh nilai berat jenis dari sampel uji 2 dan $3 \pm 2,65$ kemungkinan tanah masih berbutir kasar, sedangkan sampel uji 1 tanah berbutir halus. Hasil uji batas Atterberg dengan menggunakan grafik plastisitas Casagrande diperoleh, tanah termasuk Jenis lanau plastisitas tinggi (MH) dan lanau pasiran (ML).

Berdasarkan hasil perhitungan dan ploting data dengan menggunakan klasifikasi Skemton (1953) dan Seed (1962) dalam menentukan tingkat keaktifan dan potensi pengembangannya diperoleh bahwa, tanah di sepanjang jalan wilayah konservasi
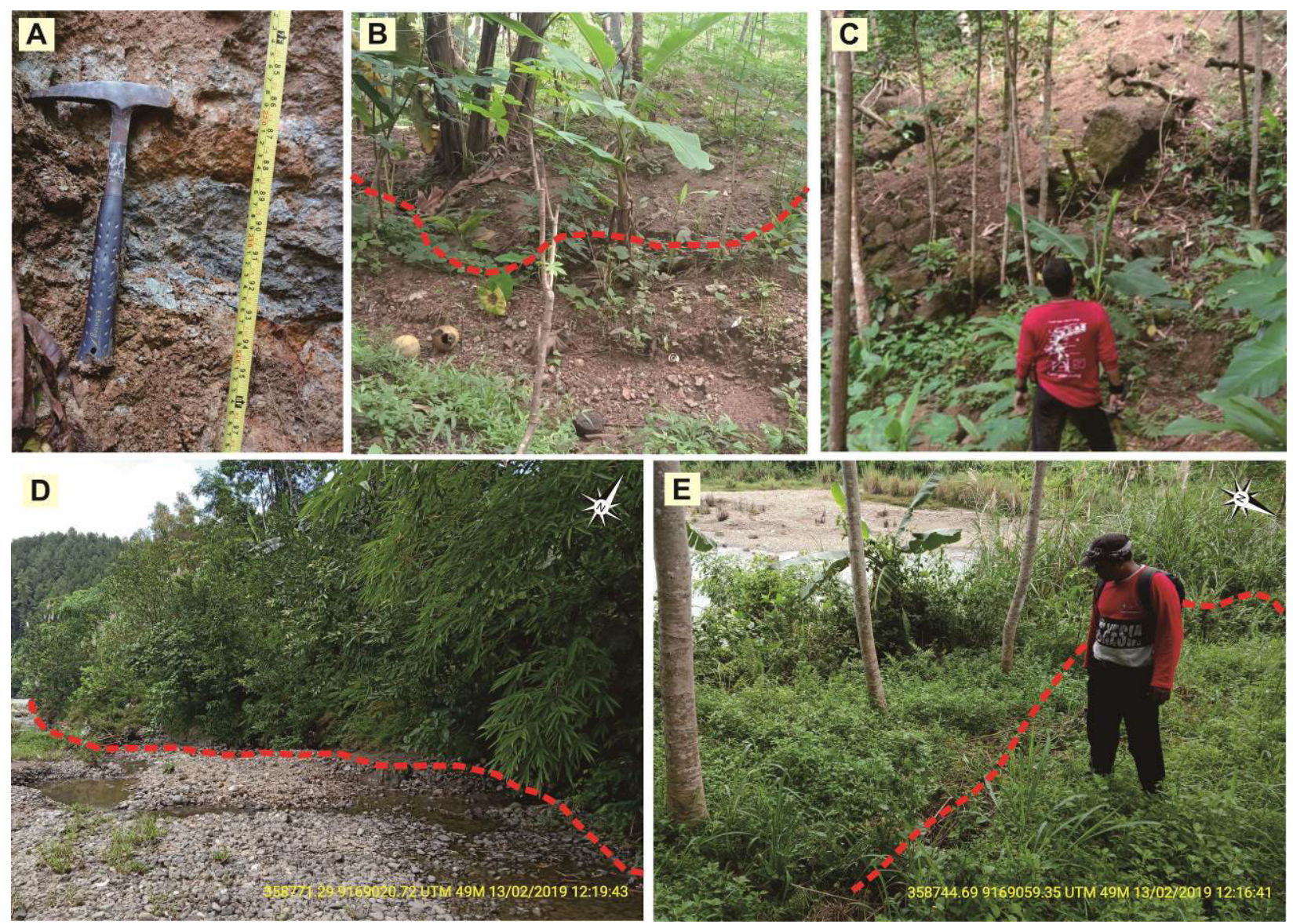

Gambar 6. Survei lapangan daerah penelitian (A. lapisan tanah yang tipis bertemu dengan batuan induk sekismika, antara zona permeabilitas dan zona impermeabilitas; B. kesan step nendatan tanah yang pernah terjadi dengan gerakan yang sangat lambat;

C. Jatuhan (rock fall) pada batuan induk berupa breksi, namun longsoran ini tidak berdampak pada lokasi perencanaan; D. bentukan permukaan yang menjorok ke arah sungai; E. bentukan permukaan terlihat ternendatkan) 
merupakan tanah dengan tingkatan normal dan tidak aktif dan potensi pengembangan sedang rendah.

\section{KESIMPULAN}

Analisa keruangan berupa aksesibilitas jalan, pola distribusi pemukiman penduduk secara umum, dan tingkat ancaman longsor merupak faktor-faktor yang utama dalam menentukan perencanaan bangunan, khususnya untuk bangunan kantor pemerintahan. Wilayah kajian secara keruangan berada pada daerah yang permukaannya menyerupai daerah tangkapan air (basin). Proses bentuklahan yang berkembang adalah pedimen, stabilitas lereng merupakan pengontrol dari pedimen yang ada pada lokasi ini. Penelitian dan pemetaan secara detail pada lokasi perencanaan bangunan dilokasi longsor sangat diperlukan. Teknik pemetaan menggunakan drone untuk memperoleh data DEM dapat dilakukan untuk analisis keruangan yang meliputi indikator-indikatir terjadinya longsor. Hal tersebut juga didukung dengan analisis lapangan dan laboratorium. Pada lokasi penelitian sifat fisik tanah untuk kestabilan lereng juga menunjukkan stabil. Bangunan fisik berupa kantor masih dapat bangun pada lokasi yang datar dan tidak ada rembesan air. Kawasan karangsambung memiliki ancaman longsor tinggi, namun masih diperlukan kajian detail pada lokasi-lokasi yang akan digunakan untuk perencanaan bangunan, sehingga tidak membatasi dalam perencanaan pembangunan.

\section{UCAPAN TERIMA KASIH}

Penulis mengucapkan terima kasih kepada Kepala Balai Informasi dan Konservasi Kebumian-LIPI atas ijinnya untuk melakukan penelitian, serta Sekretaris Daerah Kabupaten Kebumen dalam menyediakan fasilitas sehingga penelitian ini dapat dilakukan.

\section{DAFTAR PUSTAKA}

Anonim, 2015. Ikhtisar Aplikasi Google Maps, http://maps.google.com/., diakses pada 2015.

Asikin S., 1974. Evolusi Geologi Jawa Tengah dan Sekitarnya Ditinjau Dari Segi Teori Tektonik Dunia yang Baru. Fakultas Teknologi Industri. Depatemen Teknik Geologi. Institut
Peranan Geomorfologi dalam Perencanaan Bangunan pada Zona Ancaman Longsor Tinggi di Kawasan Geopark Karangsambung-Karangbolong Bagian Utara

Teknologi Bandung. Bandung.

Bösken, J. J., 2013. Geomorphology and Landscape Evolution of The ParroquiaZarzilla Region. SE Spain. Universiteit van Amsterdam, Amsterdam.

Carone, M.T., Gioia, E., Ferretti, M., and Marincioni, F., 2017. Linking Vegetation Patterns and Landslide Occurrence: An Empirical Method. Engineering Geology for Society and Territory, Vol. 2. DOI. 10.1007/978-3-319-09057-3_209.

Iskandar, A., Sadisun, I.A., Bandono, \& Nurjamil, A., 2006. Mekanisme Longsornya Kembali (Re-Sliding) Breksi Volkanik di Atas Batulempung Studi Kasus Longsoran di Daerah Gombel Kota Semarang, Jawa Tengah. Proceedings PIT IAGI Riau 2006 The 35th IAGI Annual Convention and Exhibition, Pekanbaru - Riau, 21 - 22 November 2006.

Karnawati., D., 2002. Bencana Alam Gerakan Massa di Indonesia dan Upaya Penaggulangannya. Jurusan Teknik Geologi UGM.Yogyakarta

Mulyono, A., Subardja, A., Ekasari, I., Lailati, M., Sudirja,R., and Ningrum, W., 2017. The Hydromechanics of Vegetation for Slope Stabilization. Global Colloquium on GeoSciences and Engineering 2017. IOP Conf. Series: Earth and Environmental Science 118 (2018) 012038. doi.10.1088/1755-1315/118/1/012038

Pelletier J.D., Malamud B.D., Blodgett T., Turcotte D.L., 1997. Scale-invariance of soil moisture variability and its implications for the frequency-size distribution of landslides. Engineering Geology, Vol. 48 No. 3, Hal: 255-26. https://doi.org/10.1016/S00137952(97)00041-0.

Plank S., Twele A., and Martinis S., 2016. Landslide Mapping in Vegetated Areas Using Change Detection Based on Optical and Polarimetric SAR Data. Remote Sensing, Vol. 8 No. 4 Hal: 307. DOI.10.3390/rs8040307.

Priyono, K.D., Sunarto, Sartohadi, J., dan Sudibyakto., 2011. Tipologi Pedogeomorfik Longsorlahan di Pegunungan Menoreh Kabupaten Kulonprogo Daerah Istimewa Yogyakarta. Forum Geografi, Vol. 25, No. 1, 68 Juli 2011 Hal: 67 - 84 .

Pramudjiono., Karnawati, 2008. Penanganan Bencana Gerakan Tanah Di Indonesia. Makalah Penanganan Gerakan Tanah Di 
Indoensia, Jurusan Teknik Geologi UGM, Yogyakarta. Akses online:http://pirba.hrdpnetwork.com/e5781/e5795/e6331/e15201/ eventReport15218/ diakses pada 12 April 2010 Jam 11.14 WIB.

Raharjo, P.D., 2008. Pemetaan Potensi Rawan Banjir Berdasarkan Kondisi Fisik Lahan Secara Umum Pulau Jawa. Jurnal Kebencanaan Indonesia, Vol. 1 No. 5 November 2008. Hal. 383 - 400.

Raharjo, P.D., Nur, A. M., dan Hidayat, E., 2011. Aplikasi Sistem Informasi Geografis dalam Identifikasi Kerentanan Bencana Alam di Kawasan Cagar Alam Geologi Karangsambung. Buletin Geologi Tata Lingkungan (Bulletin of Environmental Geology), Vol. 21 No. 1 April 2011 Hal. 23 -33 .

Raharjo, P.D dan Nur, A. M., 2013. Pemetaan Gerakan Tanah Kawasan Cagar Alam Geologi Karangsambung dengan Menggunakan Data Penginderaan Jauh dan SIG. Forum Geografi, Vol. 27, No. 2, Desember 992013 Hal. 99 -144

Raharjo, P.D., Hidayat, E., Winduhutomo, S., Widiyanto, K., \& Puswanto, E., 2014. Penggunaan Model Analytic Hierarchy Process untuk Penentuan Potensi Ancaman Longsor Secara Spasial. Prosiding Pemaparan Hasil Penelitian Geoteknologi LIPI 2014, Bandung: 2014 Hal. 513-525.

Sartohadi, J., 2008. The Landslide Distribution in Loano Sub-District, Purworejo District, Central Java Province, Indonesia. Forum Geografi, Vol.22, No.2, Desember 2008 Hal. 129-144.

Shara A.R.I.D., 2018. Analisis Konektivitas Wilayah di Kota Denpasar. Media Komunikasi Geografi, Vol. 19, No.1, Juni 2018, Hal. 42 - 50.

Switala, B.M., and Wei Wu., 2019. Simulation of Rainfall-Induced Landslide of The Vegetated Slope. Recent Advances in Geotechnical Research. Springer Series in Geomechanics and Geoengineering. Hal. 187-196. DOI. .org/10.1007/978-3-319-89671-7_16.

Soebowo, E., Tohari, A., Anwar, H.Z., Ruslan, M., Siswandi., Rukmana, I., dan Ramino., 2002. Pemetaan dan Perlindungan Lingkungan di Daerah Perbukitan Serta Sifat Keteknikan Lempung Ekspansif untuk Mendukung Perencanaan Tata Ruang; Aspek Geologi di Daerah Majenang - Bumiayu, Jawa Tengah.
Laporan Penelitian Sumberdaya Mineral dan Mitigasi Bencana Kebumian. Pusat Geoteknologi - LIPI. Hal. 123-137.

Vernes, D.J., 1978. Slope Movement and Type and Processes, Landslide Analysis and Control, special Report 176, Washington, D.C., Transportation Research Board, National Research Council.

Viet, T.T., Lee, G., dan Kim ,M., 2016. Shallow Landslide Assessment Considering the Influence of Vegetation Cover. Journal of the Korean Geo-Environmental Society, Vol. 17 No.4, DOI. dx.doi.org/10.14481/ jkges.2016.17.4.17.

Zakaria, Z., 2010. Model Starlet, suatu Usulan untuk Mitigasi Bencana Longsor dengan Pendekatan Genetika Wilayah (Studi Kasus: Longsoran Citatah, Padalarang, Jawa). Jurnal Geologi Indonesia, Vol. 5 No. 2 Juni 2010 Hal. 93-112.

Zuidam, R. A., 1983. Guide to Geomorphologic - aerial photographic interpretation and mapping. Enschede: Section of Geology and Geomorphology, ITC. Hal. 325. 